\title{
Indonesian English Teachers' Language Attitude towards the English Language
}

\author{
Jepri Ali Saiful \\ Applied Linguistics Department \\ Graduate School, Yogyakarta State University \\ Yogyakarta, Indonesia \\ jepriali1@gmail.com
}

\author{
Pratomo Widodo \\ Applied Linguistics Department \\ Graduate School, Yogyakarta State University \\ Yogyakarta, Indonesia \\ pratomo@uny.ac.id
}

\begin{abstract}
Language attitude study has proved vital to unveil the acceptance of indigenous people towards foreign language (FL). Unfortunately, empirical grounds exist to show that limited attentions scrutinize the FL attitude of Indonesian English teachers towards the English language. Ergo there has been a lack of knowledge on the extent to which Indonesian English teachers perceive their language of expertise. Hence, this overarching goal of this study is to address this emerging gap. This study was to investigate language attitude of Indonesian English teachers towards the English language and the difference between male and female teachers' language attitude. The participants were 82 Indonesian English teachers from the Special Region of Yogyakarta province, Indonesia who consisted of 41 males and 41 females. A questionnaire on English language attitude was used as an instrument to collect the data. The data analysis was the descriptive statistics and t-test. This study revealed that the language attitude of Indonesian English teachers towards the English language was very favorable. In other words, Indonesian English teachers had positive acceptance towards their language of expertise. Importantly, this study extended our knowledge that there was no significant difference on English language attitude between male and female Indonesian English teachers. This indicated that gender was not always become a factor that could differentiate or determine the state of individual's language attitude. It was a motivation to learn target language and the influence of printed and electronic media and region of living might affect this state of very favorable English language attitude of Indonesian English teachers.
\end{abstract}

Keywords- English language attitude; EFL teachers; gender; Indonesia

\section{INTRODUCTION}

Language attitude has become a major field of study in linguistics, psychology, and communication science [1]. Theoretical and empirical grounds have therefore proved to unveil that the language attitude per se is critical to enhance language proficiency [2] and increase language performances [3] and [4]. Likewise, the language attitude is also essential to understand the willingness of prospective English language teachers to teach English (see in [5]) and implement effective teaching methods and techniques which lead to the increasing of students' learning motivation and positive language attitude [6]. In a nutshell, language attitude is the cornerstone for the mastery of target language. Undoubtedly, it is also an avenue to develop pre-service and in-service English language teachers' professional language and pedagogical competence.

Despite the popularity and significant benefit of the language attitude, research protocols taking shape this field of inquiry are limited in numbers, particularly in the context of English teachers in Indonesia. Considerable studies have only scrutinized the English language attitude of English as a Foreign Language (EFL) pre-service teachers in Turkey (see [6]; [7]; and [5]). The other study of [8] has also merely investigated the influence of English communication skill intervention program and media of instruction on the English language attitude of pre-service English teachers in Mumbai, India. Thus, there has been a clarion call to study the English language attitude of Indonesian English teachers. In other words, there has been paucity of scientific knowledge in language attitude sphere, i.e. an extent to which Indonesian English teachers perceive their language of expertise, English. Hence, the overarching goal of this study is to address this emerging gap. This study aims to devise the English language attitude of Indonesian English teachers. Consequently, this study elicits an important insight on the nature of English language attitude of Indonesian English teachers. The insight can therefore be a reference of policy input for education stakeholders to strengthen the professional language and pedagogical competence of English teachers by increasing the state of language attitude of the teachers.

\section{LITERATURE REVIEW}

\section{A. Language Attitude}

Debates have hitherto come up to expound the concept of language attitude. Language attitude is evaluative reactions towards target language (TL) and TL communities [9]. Furthermore, language attitude as an affective experienced of learners learn the target language [10]. Besides, other looks language attitude more on behavioral predisposition or tendency [11]. In addition, in recent research, language attitude have been conceptualized as individual reactions [12] encompassing the cognitive (belief), affective (feeling or emotion), and conative (behavioral intention) (see studies of [13] and [14] ). Although this recent concept is not universally agreed by experts like [15] and [16], [17] claims that this 
tricotomy model is more comprehensive, as of the complex nature of individual's language attitude is understood easily.

In this study, the language attitude itself is more seen as evaluative responses or reactions comprising the verbal statements of belief, feeling, and tendency towards TL, the English language. The statements towards the English include following aspects [18]: the educational and social status of English, social and instrumental value of English, the use of English would detract from cultural identity, orientations towards English, the intrinsic value of English and its culture for an individual, and discomfort about native people speaking TL.

\section{B. Gender and Language Attitude}

Empirical evidences exist to juxtapose a relationship between gender and language attitude. Studies of [19] and [6] claim that female high school students have much more positive attitudes towards EFL. Consistent with the finding of [19] and [6], [18] state that female students have more positive language attitude than male students towards English in terms of the beauty, musical and culture. Moreover, [18]'s study reveals that there is no different between male and female students' language attitude in terms of English as an important, rich, and interesting language.

In contrast with the aforementioned studies, the present study of [5]demonstrates that there is no significant difference between male and female EFL prospective teachers' language attitude towards the English language. In agreement with the study of [5], in this study, male and female EFL teachers are postulated to have no difference in language attitude towards the English language. This is because gender per se is not one of the most influential factors affecting the nature of attitude of people. It is individual motivation to learn TL considered the most determinant affecting the attitude [5]. Thus, it is claimed that there is no significant difference between the state of male and female EFL teachers' language attitude towards the English language.

\section{Research Question and Hypothesis}

The research question and hypothesis of this study are formulated as follow:

- What is the nature of Indonesian English teachers' attitude towards the English language?

- $\mathrm{H}_{0}$ : there is no significant difference between male and female Indonesian English teachers' language attitude towards the English language.

$\mathrm{H}_{\mathrm{a}}$ : there is a difference between male and female Indonesian English teachers' language attitude towards the English language.

\section{RESEARCH METHODOLOGY}

\section{A. Participants}

Participants were 82 Indonesian English teachers. They were from Yogyakarta province, Indonesia. They consisted of 41 males (25 of them were senior high school teachers while
16 were junior high school teachers) and 41 females (30 of them were senior high school teachers while 11 were junior high school teachers). They were from the same English teacher organization in Yogyakarta.

\section{B. Instrument}

This study used a questionnaire on language attitude as an instrument. The questionnaire was taken from the study of [18] and modified based on the context of EFL teachers' language attitude in Indonesia. Furthermore, the questionnaire contained five aspects of language attitude towards the English and 21 statements. The statements were put in a four-point Likert scale as follows, $4=$ strongly agree, $3=$ agree, $2=$ disagree, and $1=$ strongly disagree. The following was the detailed construction of the questionnaire.

TABLE I. QUESTIONNAIRE ON INDONESIAN ENGLISH TEACHERS' ENGLISH LANGUAGE ATTITUDE

\begin{tabular}{|c|c|}
\hline $\begin{array}{l}\text { Aspects of English } \\
\text { Language Attitude }\end{array}$ & Statements \\
\hline \multirow{3}{*}{$\begin{array}{l}\text { Educational and } \\
\text { social status of } \\
\text { English }\end{array}$} & $\begin{array}{l}\text { It is a good thing to have English as the frequently } \\
\text { used foreign language in Indonesia }\left(1^{\mathrm{a}}\right) \text {. }\end{array}$ \\
\hline & $\begin{array}{l}\text { Student textbooks should be written in Bahasa } \\
\text { Indonesia (14). }\end{array}$ \\
\hline & $\begin{array}{l}\text { English should be a medium of instruction in the } \\
\text { schools in Indonesia (20). }\end{array}$ \\
\hline \multirow{4}{*}{$\begin{array}{l}\text { Social and } \\
\text { instrumental value } \\
\text { of English }\end{array}$} & English is the mark of an educated person (2). \\
\hline & $\begin{array}{l}\text { If I use English, I will be praised and approved of } \\
\text { by my family, relatives and friends (4). }\end{array}$ \\
\hline & If I use English, my status is raised (12). \\
\hline & $\begin{array}{l}\text { The spread of the use of English is one of the most } \\
\text { crucial factors in Indonesia's } \\
\text { development today (17). }\end{array}$ \\
\hline \multirow{3}{*}{$\begin{array}{l}\text { The use of English } \\
\text { would detract from } \\
\text { cultural identity }\end{array}$} & $\begin{array}{l}\text { When using English, I do not feel that I am } \\
\text { Indonesian any more (3). }\end{array}$ \\
\hline & $\begin{array}{l}\text { At times I fear that by using English I will become } \\
\text { like an native English speaker (5). }\end{array}$ \\
\hline & $\begin{array}{l}\text { If I use English, it means that I am not patriotic } \\
\text { (11). }\end{array}$ \\
\hline \multirow[t]{7}{*}{$\begin{array}{l}\text { Orientation towards } \\
\text { English }\end{array}$} & $\begin{array}{l}\text { I am forced to learn English by the people around } \\
\text { me (6). }\end{array}$ \\
\hline & I like reading English magazines, books, etc (7). \\
\hline & I do not feel awkward when using English (8). \\
\hline & I love talking with native speakers in English (9). \\
\hline & $\begin{array}{l}\text { I wish that I could speak fluent and accurate } \\
\text { English (15). }\end{array}$ \\
\hline & $\begin{array}{l}\text { I feel uneasy and lack confidence when speaking } \\
\text { English (16). }\end{array}$ \\
\hline & $\begin{array}{l}\text { I would take English training or course to improve } \\
\text { my English skills (18). }\end{array}$ \\
\hline \multirow{2}{*}{$\begin{array}{l}\text { The intrinsic value } \\
\text { of the English } \\
\text { language and } \\
\text { English based } \\
\text { culture }\end{array}$} & I like to see English speaking films (10). \\
\hline & $\begin{array}{l}\text { The command of English is very helpful in } \\
\text { understanding English communities and their } \\
\text { cultures (21). }\end{array}$ \\
\hline \multirow{2}{*}{$\begin{array}{l}\text { Discomfort about } \\
\text { Indonesian } \\
\text { speaking English }\end{array}$} & $\begin{array}{l}\text { I feel uncomfortable when hearing Indonesians } \\
\text { speaking to another in English (13). }\end{array}$ \\
\hline & $\begin{array}{l}\text { I feel uneasy when hearing an Indonesian speaking } \\
\text { English (19). }\end{array}$ \\
\hline
\end{tabular}

In addition, the questionnaire was tried out to $30 \mathrm{EFL}$ teachers in Yogyakarta apart from the participants to check the 
validity. The result revealed that all items of questions in the questionnaire were valid proven by the score of Correlated Item-Total Correlation above 0,300. Besides, in term of the reliability, the results of Alpha Cronbach test showed that the questionnaire was reliable with a score of Aplha index higher than 0.70, 0.839. Above all, the questionnaire was valid and reliable to be used to get data on the language attitude of Indonesian English teachers towards the English language.

\section{Data Analysis}

Descriptive statistic and t-test were administrated to analyze the data with two different procedures. The first was descriptive statistics test to get data on the state or nature of participants' language attitude towards the English language. This descriptive statistics was to answer the research question of this study. Furthermore, the second was t-test. The t-test was to examine the hypothesis of this study. The t-test was performed after the prerequisite tests of normality and homogeneity. The prerequisite tests revealed that the data of male teachers' statements were normal proven by a score of 0.68 in Kolmogorov-Smirnov test while Shapiro-Wilk test gained 0.258. Furthermore, the data of female teachers' statements were also normal; the score of Kolmogorov-Smirnov test was 0.200 while Shapiro-Wilk test gained 0.527. Besides, the homogeneity test showed that the data of male and female Indonesian English teachers' language attitude were homogeny. It was proven by significant score of Levene test above $0.05,0.404$.

\section{RESULTS AND DISCUSSION}

\section{A. Results}

\section{1) Descriptive Statistics}

The following is the results of descriptive statistics of Indonesian English teachers' language attitude.

TABLE II. GROUP STATISTICS

\begin{tabular}{|ll|r|r|r|r|}
\hline & Sex & $\boldsymbol{N}$ & \multicolumn{1}{c|}{ Mean $^{\boldsymbol{a}}$} & $\begin{array}{c}\text { Std. } \\
\text { Deviation }\end{array}$ & $\begin{array}{c}\text { Std. Error } \\
\text { Mean }\end{array}$ \\
\hline $\begin{array}{l}\text { Language } \\
\text { Attitude }\end{array}$ & Male & 41 & 70.9024 & 4.77915 & .74638 \\
\cline { 3 - 6 } & Female & 41 & 69.3415 & 3.81189 & .59532 \\
\hline
\end{tabular}

Table 1 showed that the mean score of male and female gender was in the "very favorable" category. This indicated that both male and female Indonesian English teachers have very favorable language attitude towards the English language.

\section{2) T-test}

TABLE III. INDEPENDENT SAMPLE TEST

\begin{tabular}{|c|c|c|c|c|}
\hline & \multicolumn{3}{|c|}{ T-test for Equality of Means } \\
\hline & & $D f$ & Sig. (2 tailed) & $\begin{array}{c}\text { Mean } \\
\text { Difference }\end{array}$ \\
\hline \multirow{2}{*}{$\begin{array}{l}\text { Language } \\
\text { Attitude }\end{array}$} & $\begin{array}{l}\text { Equal } \\
\text { variances } \\
\text { assumed }\end{array}$ & 80 & .106 & 1.56098 \\
\hline & $\begin{array}{l}\text { Equal } \\
\text { variances not } \\
\text { assumed }\end{array}$ & 76.231 & .106 & 1.56098 \\
\hline
\end{tabular}

Table 3 revealed that the score of t-test for equality of means was higher than t-table $(p>0.05), p=0.106, \mathrm{df}=80$ and $p=106$, $\mathrm{df}=76.231$. This result demonstrated that there was no significant difference between male and female Indonesian English teachers' language attitude towards the English. Meaning, $\mathrm{H}_{0}$ was accepted while $\mathrm{H}_{\mathrm{a}}$ was rejected.

\section{B. Discussion}

The overarching goal of this study is to investigate Indonesian English teachers' language attitude towards the English language. The result of descriptive statistics demonstrates that both male and female Indonesian English teachers have very favorable language attitude towards the English language. This result - based upon the perspectives of [9] and [10] - indicates that the Indonesian English teachers have positive reaction towards the TL. In that sense, the Indonesian English teachers have positive acceptance towards their language of expertise, English. They have positive proposition on the educational and social status, social and instrumental value, and the intrinsic value of the English language and cultures. Likewise, they have positive orientation and tendency towards English. Furthermore, they also feel comfortable when hearing native people of Indonesia speaking English. Importantly, they also feel that the use of English would not detract from their cultural identity.

In addition, the result of t-test reveals that there is no significant difference between male and female Indonesian English teachers' language attitude towards the English language. This result indicates that both male and female teachers have the same state of very favorable language attitude towards the TL. Although this result conflicts with the study of [6]; [18]; and [19], the score of t-test for equality of means, $\mathrm{p}=0.106$, $\mathrm{df}=80$ and $\mathrm{p}=106$, $\mathrm{df}=76.231$, shows compelling evidence that there is sorely no difference in language attitude in terms of gender. Exist to support the result of this study, the finding of [5] shows the same that there is no significant difference between male and female EFL prospective teachers' English language attitude. In short, this result extends our knowledge that gender is not always become a determinant to affect the state or nature of individual's language attitude.

This claim is due to the fact that gender is not a major factor to affect the attitude of people. It is the motivation of the teachers to learn the English, in view of [5], can induce the 
nature of language attitude. In addition, pondering subsequent scholarship postulates that media could affect and penetrate people's mind [20]; [21]; and [22] and attitude [23] and [24], along with present an empirical ground shows that area of living influences language attitude (see [25]), this study thus posits that the role of media and region where the teachers are living causes this no difference language attitude in term of gender.

The teachers are living in the Special Province of Yogyakarta, Indonesia. This special region is reported as a heart of international tourist destination in central Java [26] and therefore the exposures of English language in both printed and electronic media are ubiquitous. Consequently, the inhabitants get used to the existence of the English language and they are accustomed to using the language as a mean of communication with tourists. The logical consequence emerges that this could possibly affect the state of favorable attitude of the teachers towards the English language. In other words, the beliefs, feelings, and predispositions of the teachers towards the English language become positive. However, to certain extent, further examination is still needed to investigate this causal relationship.

\section{CONCLUSION}

The major highlight of this study contributes to knowledge field of language attitude and communication is that Indonesian English teachers have very favorable attitude towards the English language. In that sense, they have positive acceptance towards the use and existence of the English language. In addition, this study devises an important insight that gender is not always become a major antecedent to influence the state of individual's language attitude. The result of t-test demonstrates that both male and female Indonesian English teachers have the same nature of language attitude towards English. This result of no difference in language attitude in terms of gender is postulated due to the influence of media and region where the teachers live.

Although this study has shed light pivotal insights on the Indonesian English teachers' language attitude towards the English language, in many respects, this study still has a limitation. This study has not yet researched the influence of media and region of living on the state of English language attitude of Indonesian English teachers. However, theoretical and empirical grounds have been provided to expound how media and region where the teachers live can affect the state of Indonesian English teachers' language attitude towards the English language.

\section{ACKNOWLEDGMENT}

The researchers express special gratitude to participants who were so cooperative to fill the questionnaire during the data collection process of this study. Furthermore, Jepri Ali Saiful thanks to Lembaga Pengelola Dana Pendidikan (LPDP)/ Indonesian Endowment Fund for Education for giving Mr. Saiful full scholarship to pursue study in Applied
Linguistics Department, Graduate School, Yogyakarta State University, Indonesia.

\section{REFERENCES}

[1] H. Giles and A. C. Billings, "Assessing language attitudes: Speaker evaluation studies,” in The handbook of applied linguistics, A. Davies and C. Elder, Eds. Malden: Blackwell, 2004, pp. 187-208.

[2] H. D. Brown, Principles of language learning and teaching. New York: Longman, 2000.

[3] A. L. Latifah, M. Fadzil, R. Bahroom, and W. Mohamad, "The role of motivation, attitude, anxiety and instrumental orientation in influencing learners' performance in English as a second language in OUM,” in Global Learn Asia Pacific 2011 - Global Conference on Learning and Technology, 2011, pp. 1-11.

[4] M. Visser, "Learning under conditions of hierarchy and discipline: The case of the German Army, 1939-1940,” Learn. Inq., vol. 2, no. 2, pp. 127-137, 2008.

[5] B. Güryay, "Individual variables, attitudes towards English and being a teacher: A study on prospective teachers of English,” Int. J. Psychol. Educ. Stud., vol. 3, no. 2, pp. 14-23, 2016.

[6] E. Gursoy, "Prospective ELT teachers' attitudes toward the English language in an EFL context,” J. Int. Educ. Res., vol. 9, no. 1, pp. 107114, 2013.

[7] A. Arikan, "Prospective English language teachers' perceptions of the target language and culture in relation to their socioeconomic status," English Lang. Teach., vol. 4, no. 3, pp. 232-242, 2011.

[8] M. A. Ansari and S. Pandya, "Prospective Teachers' Attitude towards English,” in APCAR-2016, 2016, pp. 352-358.

[9] R. C. Gardner, Social psychology and second language learning: The role of attitudes and motivation. London: Edward Arnold, 1985.

[10] A. M. Masgoret and R. C. Gardner, “Attitudes, motivation, and second language learning: A metaanalysis of studies conducted by Gardner and associates,” Attitudes, Motiv. Second Lang. Learn. A Meta-Analysis Stud. Conduct. by Gardner Assoc., vol. 53, no. S1, pp. 167-210, 2003.

[11] B. D. Katz, "The functional approach to the study of attitudes," Public Opi. Quar., vol. 24, no. 2, pp. 163-204, 1960.

[12] C. Schoel et al., “'Attitudes Towards Languages’ (AToL) Scale: A Global Instrument,” J. Lang. Soc. Psychol., vol. 20, no. 10, pp. 1-25, 2012.

[13] M. J. Z. Abidin, M. Pour-Mohammadi, and H. Alzwari, "EFL students' attitudes towards learning English language: The case of Libyan secondary school students,” Asian Soc. Sci., vol. 8, no. 2, pp. 119-134, 2012.

[14] V. Aryadoust, P. Mehran, and M. Alizadeh, "Validating a computerassisted language learning attitude instrument used in Iranian EFL context: an evidence-based approach,” Comput. Assist. Lang. Learn., vol. 29, no. 3, pp. 561-595, 2015.

[15] C. Mantle-Bromley, "Positive attitudes and realistic beliefs: links to proficiency,” Mod. Lang. J., vol. 79, no. 3, pp. 372-386, 1995.

[16] C. Mantle-Bromley and R. B. Miller, "Effect of multicultural lessons on attitudes of students of Spanish,” Mod. Lang. J., vol. 75, no. 4, pp. 418-425, 1991.

[17] R. M. McKenzie, The social psychology of English as a global language: Attitudes, awareness and identity in the Japanese context, Educationa. London: Springer, 2010.

[18] F. Karahan, "Language attitudes of Turkish students towards the English language and its use in Turkish context,” J. Arts Sci., vol. 1, no. 7, pp. 73-87, 2007.

[19] S. Ina, E. I. Ercan, and A. S. Saracaloğlu, "The Relation Between Students' Attitudes Toward Foreign Language and Foreign Language Achievement,” Lang. J., vol. 130, pp. 37-52, 2005.

[20] M. K. Yusuf and A. Liman, “'Virtual cultural resonance' as an evidence for ' Media effect by consent ': Notes on media audience theories and proposing new,” Int. J. Humanit. Soc. Stud., vol. 3, no. 11, pp. 91-95, 2015. 
[21] S. Kenechukwu, "Understanding media effect: A study of how studies in perception nailed the coffin on Magic Bullet Theory,” Int. J. Soc. Sci. Humanit. Rev., vol. 5, no. 2, pp. 115-122, 2015.

[22] W. R. Neuman and L. Guggenheim, "The evolution of media effects theory : A six-stage model of cumulative research,” Commun. Theory, vol. 21, pp. 169-196, 2011.

[23] C. Happer and G. Philo, "Special thematic section on ' Societal Change ' the role of the media in the construction of public belief and social change methods: Content analysis,” J. Soc. Polit. Psychol., vol. 1, no. 1, pp. 321-336, 2013
[24] A. Reevas and R. de Vries, "Does media coverage influence public attitudes towards welfare receipents? The impact of the 2011 English riots," Br. J. Sociol., vol. 67, no. 2, pp. 281-306, 2016.

[25] X. Gonzalez-Riano, I. Hevia-Artime, and A. Fernandez-Costales, "Language attitudes of Asturian students in the area of Navia-Eo (Spain),” Lang. Intercult. Commun., vol. 13, no. 4, pp. 450-469, 2013.

[26] M. P. Hampton, "Entry points for local tourism in developing countries: Evidence from Yogyakarta, Indonesia,” Geogr. Ann., vol. 85, no. 2, pp. 85-101, 2016. 